\title{
Radiation Therapy for Hepatocellular Carcinoma with Portal Vein Tumor Thrombosis
}

\author{
Seung Gyu Park, M.D.*, Jin Hee Kim, M.D., Ph.D.*, Sang Jun Byun, M.D.*, Ok Bae Kim, M.D., Ph.D.*, \\ Jae Seok Hwang, M.D., Ph.D. ${ }^{\dagger}$, Young Kee Oh, Ph.D.* and Tae Jin Choi, Ph.D. ${ }^{\dagger}$ \\ Departments of ${ }^{*}$ Radiation Oncology, ${ }^{\dagger}$ Internal Medicine and ${ }^{\dagger}$ Medical Engineering, Dongsan Medical \\ Center, Keimyung University School of Medicine, Daegu, Korea
}

\begin{abstract}
Purpose: To evaluate the effectiveness of radiation therapy (RT) for hepatocellular carcinoma (HCC) with portal vein tumor thrombosis (PVTT) and to analyze the prognostic factors.

Materials and Methods: From December 2004 to April 2009, 70 patients who had HCC with PVTT were treated with RT at Keimyung University Dongsan Medical Center. Nineteen patients whose total dose was below 30 Gy and one patient who underwent liver transplantation were excluded. The remaining 50 patients (45 males, 5 females; median age 55 years) were analyzed. According to the LCSGJ TNM stage, there were 27 patients (54.0\%) with stage III and 23 (46.0\%) with stage IV. Total dose of 30 54 Gy was administered (median 45). Thirty patients $(60.0 \%)$ were treated with concurrent chemoradiation therapy (CCRT). The median follow-up duration was from 13.5 months (range, 3 to 70 months).

Results: The median survival time from the start of RT was 9 months. One-year and 2-year overall survival rates were $24.9 \%$ and $11.2 \%$, respectively. At the follow-up time, three patients $(6.0 \%)$ displayed no evidence of disease. Seven patients (14.0\%) were alive with disease, and $40(80.0 \%)$ patients had expired due to disease progression. CCRT was associated with worse survival than RT alone $(p=0.034)$. Response to RT $(p=0.037)$, CLIP stage $(p=0.017)$, and TNM stage $(p=0.041)$ were statistically significant prognostic factors. There was no radiation-induced liver disease.

Conclusion: RT is an effective and safe modality for HCC with PVTT. Further studies such as prospective randomized trials are needed to confirm the role of RT for HCC with PVTT.
\end{abstract}

Key Words: Hepatocellular carcinoma, Portal vein, Radiotherapy, Concurrent chemoradiotherapy

\section{Introduction}

Hepatocellular carcinoma (HCC) is a complex disease that is the third most common cause of cancer-related deaths worldwide. $^{1,2)}$ In association with viral hepatitis, HCC is particularly prevalent in Asia. Portal vein tumor thrombosis (PVTT) has been reported in about 50\% of HCC patients, and the survival time is under $2 \sim 4$ months without specific treatments. $^{3 \sim 5)}$ Consensus treatment in HCC, including surgical resection and transarterial chemoembolization (TACE), are not satisfactory in HCC with PVTT, because of the lack of portal

Submitted December 15, 2010, accepted March 15, 2011

Reprint requests to Jin Hee Kim, M.D., Ph.D., Department of Radiation Oncology, Dongsan Medical Center, Keimyung University, 194 Dongsan-dong, Jung-gu, Daegu 700-712, Korea

Tel: 053)250-7665, Fax: 053)250-7984

E-mail: jhkim@dsmc.or.kr blood flow. ${ }^{6 \sim 9)}$

Advancements in radiation therapy (RT) techniques have increased the HCC treatment efficiency. RT in HCC with PVTT tends to improve survival by $8 \sim 13$ months. $^{10 \sim 14)}$ Although RT seems to have a survival benefit, the prognostic influence of various factors is debatable. ${ }^{15)}$ This study was designed to evaluate the effectiveness of RT and to analyze the prognostic factors in HCC with PVTT.

\section{Materials and Methods}

\section{Patient characteristics}

We retrospectively reviewed 70 HCC patients with PVTT who were referred for RT at Keimyung University Dongsan Medical Center from December 2004 to April 2009. The diagnosis of HCC was based on the Korean Liver Cancer 
Study Group and National Cancer Center, Korea guidelines, pathological confirmation or a compatible radiological finding in two different imaging modalities with $\alpha$-fetoprotein (AFP) level below $200 \mathrm{ng} / \mathrm{mL}$, or compatible radiological finding in one imaging modality with AFP level above 200, or presence of hepatic mass above $2 \mathrm{~cm}$ in one imaging modality with previous liver cirrhosis. ${ }^{16)}$ The diagnosis of PVTT was based on radiologic findings using dynamic contrast enhanced computed tomography (CT) or magnetic resonance imaging (MRI) and on abnormal filling defect within the lumen of the portal vein. ${ }^{17)}$ PVTT was classified to three groups by its location, main trunk, first branch and second branch. If multiple PVTT was located, the PVTT was classified in the proximal category. Seventy patients were treated by RT. However, 19 patients whose total dose was below 30 Gy and 1 patient who underwent liver transplantation were excluded. Clinical data of 50 patients were analyzed.

Patients' characteristics are shown at Table 1. Patients' performance status was evaluated with Eastern Cooperative Oncology Group (ECOG) performance status. The extent of tumors was evaluated using the Liver Cancer Study Group of Japan (LCSGJ) TNM stage, and in association of liver function, Child-Pugh classification and the Cancer of the Liver Italian Program (CLIP) staging system. ${ }^{18 \sim 20)}$ Twenty patients (40.0\%) received RT alone and 30 patients (60.0\%) received concurrent chemoradiation therapy (CCRT) via hepatic artery infusion chemotherapy (HAIC). The chemotherapeutic agents mainly combined with 5-fluorouracil (5-FU), cis-diamminedichloroplatinum (CDDP) and leukovorin. 5-FU (250 mg/day), CDDP (10 mg/day) and leukovorin $(12 \mathrm{mg} /$ day $)$ were delivered for 5 days every 3 to 4 weeks. Number of chemotherapeutic cycles was different for each patient $(2 \sim 10$ cycles; median 3 cycles).

\section{Radiation therapy}

Patients were treated while in the supine position with both arms raised above the head, using a three-dimensional conformal technique. Gross tumor volume (GTV) included PVTT area and adjacent primary tumor site. Primary tumor was excluded from the GTV when separated from the PVTT area, or the proportion of liver irradiated was more than $2 / 3$ of the liver. Planned target volume (PTV) included GTV $+1 \sim 2 \mathrm{~cm}$ in all directions. A total dose of 30 54 Gy (median, 45 Gy)
Table 1. Patient Characteristics

\begin{tabular}{|c|c|}
\hline Characteristics & No. of patients $(\%)$ \\
\hline \multicolumn{2}{|l|}{ Age } \\
\hline$<55$ & $24(48.0)$ \\
\hline$\geq 55$ & $26(52.0)$ \\
\hline \multicolumn{2}{|l|}{ Gender } \\
\hline Male & $45(90.0)$ \\
\hline Female & $5(10.0)$ \\
\hline \multicolumn{2}{|l|}{ ECOG $^{*}$} \\
\hline 0 & $18(36.0)$ \\
\hline 1 & $32(64.0)$ \\
\hline \multicolumn{2}{|l|}{ Portal vein thrombosis } \\
\hline Main trunk & $16(32.0)$ \\
\hline First branch & $24(48.0)$ \\
\hline Second branch & $10(20.0)$ \\
\hline \multicolumn{2}{|l|}{ TNM stage } \\
\hline III & $27(54.0)$ \\
\hline IV & $23(46.0)$ \\
\hline \multicolumn{2}{|l|}{$\mathrm{CLIP}^{\dagger}$ stage } \\
\hline 1 & $9(18.0)$ \\
\hline 2 & $18(36.0)$ \\
\hline 3 & $11(22.0)$ \\
\hline 4 & $10(20.0)$ \\
\hline 5 & $2(4.0)$ \\
\hline \multicolumn{2}{|l|}{$\mathrm{AFP}^{\ddagger}$} \\
\hline$\leq 400$ & $21(42.0)$ \\
\hline$>400$ & $29(58.0)$ \\
\hline \multicolumn{2}{|l|}{ Child-Pugh class } \\
\hline $\mathrm{A}$ & $39(78.0)$ \\
\hline B & $11(22.0)$ \\
\hline \multicolumn{2}{|l|}{ Previous treatment } \\
\hline $\mathrm{TACE}^{\S}$ or PEIT & $39(78.0)$ \\
\hline No treatment & $11(22.0)$ \\
\hline
\end{tabular}

*Eastern Cooperative Oncology Group, ${ }^{\dagger}$ Cancer of the Liver Italian Program, ${ }^{\dagger}$ alpha-fetoprotein, ${ }^{\S}$ transarterial chemoembolizaion, "percutaneous ethanol injection therapy.

was irradiated 5 days per week, 1.8 2.0 Gy once a day. The biologically effective dose (BED) as the $\alpha / \beta$ ratio=10, 36 $63 \mathrm{~Gy}_{10}$ (median, 53) was irradiated. The primary tumor, PVTT, normal liver tissue, kidney and spinal cord were contoured and the radiation doses to each organ were measured. $\mathrm{V}_{50 \%}$ (fraction of the non-tumorous liver treated with more than $50 \%$ of the prescribed dose) of the normal liver were calculated and the treatment dose was selected according to guidelines published by the University of Michigan or Yonsei University to prevent radiation-induced liver disease (RILD). ${ }^{21,22)}$ The lower total dose was selected between the two different guidelines. For preservation of normal tissue, more than $33 \%$ of kidney volume did not receive more than $18 \mathrm{~Gy}$, the maximal dose to the spinal cord was no more than 45 Gy and the dose to the small bowel and 
stomach was no more than $50 \mathrm{~Gy}$.

\section{Follow-up}

Median follow-up period was 13.5 months (range, 3 to 70 months). During RT, physical examinations and liver function tests were performed once a week. After the completion of RT, CT or MRI examination was conducted $1 \sim 3$ months later. Liver function was tested and tumor marker was followed. Complete disappearance of the primary tumor and PVTT was defined as complete response (CR), a >50\% reduction of the longest diameter of the irradiated volume was defined as partial response (PR), a $<50 \%$ reduction of the longest diameter or no change was defined as stable disease (SD) and growth of the tumor was defined as progressive disease (PD). RILD was defined as either a minimum 2-fold increase in anicteric elevation of alkaline phosphatase and non-malignant ascites, or a minimum 5-fold increase in elevated transaminase levels over the upper limit of normal or pretreatment levels in the absence of documented progressive disease. $^{21)}$ Evaluation of RILD was performed until 3 months after RT.

\section{Statistical analyses}

Survival statistics were calculated from day 1 of RT. The Kaplan-Meier method was used to estimate overall survival (OS) rates. Univariate analysis associated with survival was performed using log-rank test to evaluate the association between survival time and various factors. The chi-square test and Fisher's exact test were used to evaluate association between tumor response and factors. And $\mathrm{p}<0.05$ was considered as statistically significant. The statistical analyses were performed with SPSS ver. 17.0 (SPSS Inc., Chicago, IL, USA).

\section{Results}

\section{Response and survival time}

Of the 48 patients who received follow-up CT or MRI after completion of RT, tumor response was observed in 26 patients (54.2\%; two CR and $24 \mathrm{PR}$ ), SD was observed in 15 patients $(31.2 \%)$ and PD was observed in 7 patients (14.6\%). At the time of analysis, there were 3 patients $(6.0 \%)$ with alive with no evidence of disease, 7 patients $(14.0 \%)$ were alive with

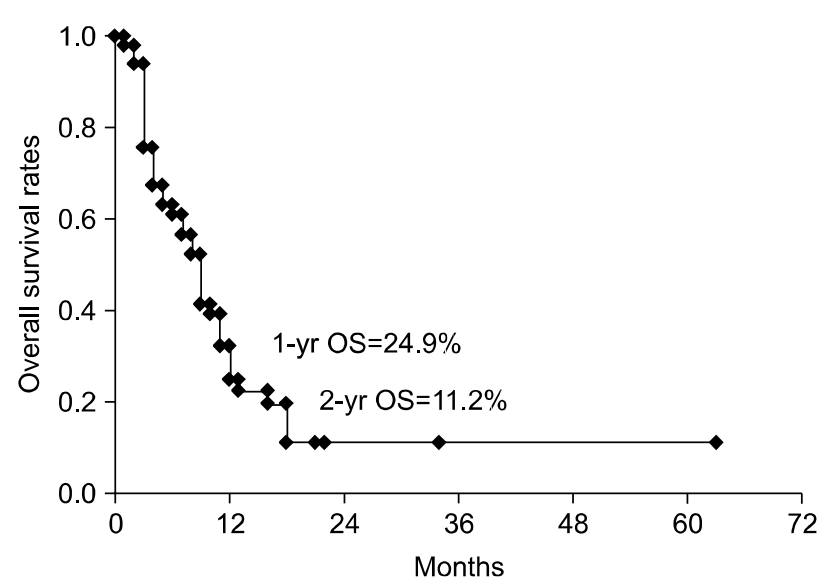

Fig. 1. Overall survival (OS) rage.

disease. Forty patients (80.0\%) expired due to disease progression. The median survival time after RT was 9 months (range, 1 to 63 months). One-year and 2-year survival rate was $24.9 \%$ and $11.2 \%$, respectively (Fig. 1).

\section{Prognostic factors}

The relationship between survival time and various factors are summarized in Table 2. RT alone versus CCRT was a significant factor $(\mathrm{p}=0.034)$, and RT alone was predictive of a longer survival time (median survival time 12 vs. 7 months) (Fig. 2). Tumor response after RT was also a significant factor $(\mathrm{p}=0.037)$; tumor responder $(\mathrm{CR}$ or $\mathrm{PR})$ predicted a longer survival time (median survival time 11 vs. 5 months) than non-responder (SD or PD). TNM stage associated with tumor extent was also a significant factor $(\mathrm{p}=0.041)$; a longer survival time was predicted for stage III patients $(n=27)$ compared to stage IV patients (median survival time 11 vs. 5) (Fig. 3). CLIP stage associated with liver function and tumor aggressiveness was also a significant factor $(p=0.017)$. When CLIP stage was divided to two categories, stage 1 group and stage 2 to 5 group, it was associated with survival time, but was not statistically significant $(\mathrm{p}=0.086)$. Thirty-nine patients received a previous treatment including TACE or percutaneous ethanol injection therapy (PEIT). There were no differences in survival time and tumor response between these patients and those that did not previously received treatment $(p=0.646$ in survival time, $\mathrm{p}=0.515$ in tumor response). There was no statistical significance concerning treatment related factors such as total radiation dose or BED. There was also no 
Table 2. Univariate Analysis for Prognostic Factors

\begin{tabular}{|c|c|c|}
\hline Characteristics & $\mathrm{MS}^{*} \pm \mathrm{SE}^{\dagger}(\mathrm{mo})$ & p-value \\
\hline \multicolumn{3}{|l|}{ Age } \\
\hline$<55$ & $8 \pm 2.876$ & 0.476 \\
\hline$\geq 55$ & $9 \pm 0.793$ & \\
\hline \multicolumn{3}{|l|}{ Gender } \\
\hline Male & $9 \pm 0.898$ & 0.818 \\
\hline Female & 3 & \\
\hline \multicolumn{3}{|l|}{$\mathrm{ECOG}^{\dagger}$} \\
\hline 0 & $10 \pm 2.211$ & 0.523 \\
\hline 1 & $8 \pm 0.905$ & \\
\hline \multicolumn{3}{|l|}{ Underlying liver disease } \\
\hline Hepatitis B & $9 \pm 2.173$ & 0.347 \\
\hline \multicolumn{3}{|l|}{ Hepatitis C } \\
\hline None & $9 \pm 1.080$ & \\
\hline \multicolumn{3}{|l|}{ Biologically effective dose } \\
\hline$\leq 53 \mathrm{~Gy}_{10}$ & $9 \pm 0.842$ & 0.480 \\
\hline$>53 \mathrm{~Gy}_{10}$ & $12 \pm 6.619$ & \\
\hline \multicolumn{3}{|l|}{ Combination therapy } \\
\hline Radiation therapy alone & $12 \pm 2.030$ & 0.034 \\
\hline $\mathrm{CCRT}^{\S}$ & $7 \pm 1.958$ & \\
\hline \multicolumn{3}{|l|}{ Treatment response } \\
\hline Responder & $11 \pm 1.575$ & 0.037 \\
\hline Non-responder & $5 \pm 2.217$ & \\
\hline \multicolumn{3}{|l|}{ TNM stage } \\
\hline III & $11 \pm 1.625$ & 0.041 \\
\hline IV & $5 \pm 1.125$ & \\
\hline \multicolumn{3}{|l|}{ CLIP stage" } \\
\hline 1 & $11 \pm 2.981$ & 0.017 \\
\hline 2 & $9 \pm 1.164$ & \\
\hline 3 & $9 \pm 3.869$ & \\
\hline 4 & $3 \pm 0.387$ & \\
\hline 5 & 10 & \\
\hline \multicolumn{3}{|l|}{$\mathrm{AFP}^{\pi}$} \\
\hline$\leq 400$ & $9 \pm 0.682$ & 0.918 \\
\hline$>400$ & $10 \pm 2.839$ & \\
\hline \multicolumn{3}{|l|}{ Child-Pugh class } \\
\hline A & $9 \pm 1.188$ & 0.459 \\
\hline B & $9 \pm 2.905$ & \\
\hline \multicolumn{3}{|l|}{ Previous treatment } \\
\hline $\mathrm{TACE}^{* *}$ or PEIT ${ }^{\dagger \dagger}$ & $8 \pm 0.989$ & 0.646 \\
\hline No treatment & $10 \pm 2.255$ & \\
\hline
\end{tabular}

statistical significance concerning on age, gender, history of previous liver disease including hepatitis B or C, level of AFP $(\leq 400$ or $>400)$ or Child-Pugh classification.

The relationship between tumor response and various factors such as radiation dose, combination therapy, TNM stage or location of PVTT were also analyzed (Table 3); there were no statistically significant factors that influenced tumor response.

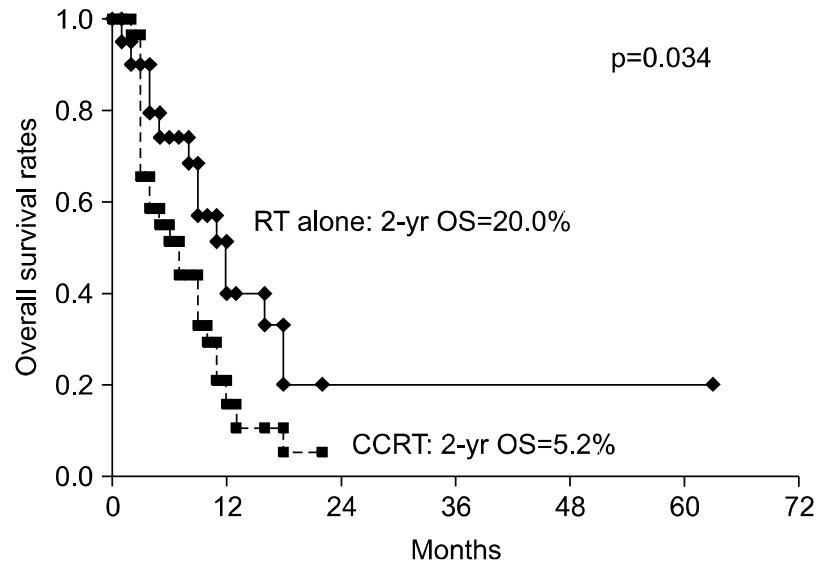

Fig. 2. Overall survival (OS) rate according to combination modality (radiation therapy [RT] alone vs. concurrent chemoradiation therapy [CCRT]).

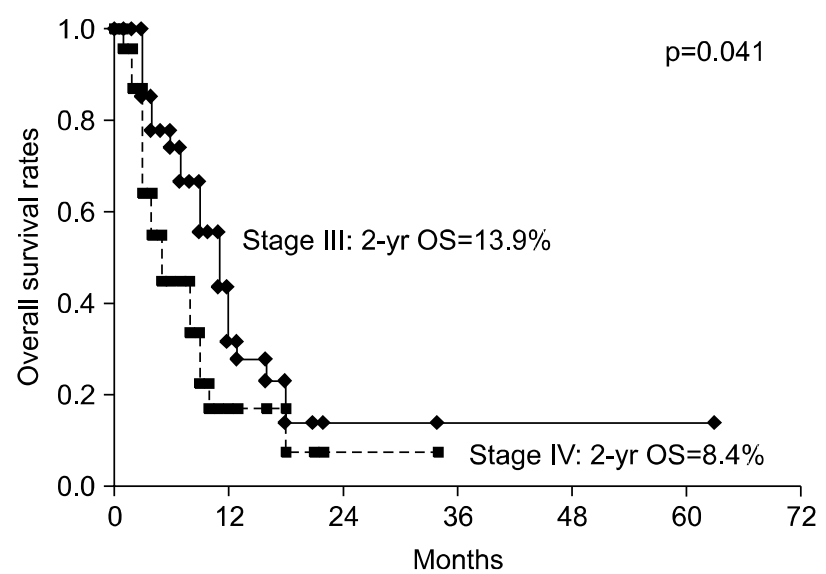

Fig. 3. Overall survival (OS) rate according to Liver Cancer Study Group of Japan (LCSGJ) TNM staging system.

\section{Complications}

There was no specific laboratory findings or clinical symptoms of RILD observed from start of RT to 3 months after RT. There was no grade 3 or 4 gastrointestinal toxicity. Grade 1 or 2 gastrointestinal toxicity was not evaluated because of insufficient medical records.

\section{Discussion and Conclusion}

HCC with PVTT indicates an advanced stage that can lead to widespread dissemination of tumors and marked deterioration of hepatic function. No definite treatment strategy 
Table 3. Prognostic Factors Affecting Treatment Response

\begin{tabular}{|c|c|c|c|}
\hline Characteristics & $\begin{array}{l}\text { Responder } \\
\quad(n=26)\end{array}$ & $\begin{array}{l}\text { Non-responder } \\
\quad(n=22)\end{array}$ & p-value \\
\hline \multicolumn{4}{|l|}{ Age } \\
\hline$<55$ & 13 & 9 & \multirow{2}{*}{0.529} \\
\hline$\geq 55$ & 13 & 13 & \\
\hline \multicolumn{4}{|l|}{ Gender } \\
\hline Male & 24 & 19 & \multirow[t]{2}{*}{$0.649^{\pi}$} \\
\hline Female & 2 & 3 & \\
\hline \multicolumn{4}{|l|}{$\mathrm{ECOG}^{*}$} \\
\hline 0 & 11 & 6 & \multirow[t]{2}{*}{0.278} \\
\hline 1 & 15 & 16 & \\
\hline \multicolumn{4}{|l|}{$\begin{array}{l}\text { Biologically effective } \\
\text { dose }\end{array}$} \\
\hline$\leq 53 \mathrm{~Gy}_{10}$ & 19 & 17 & \multirow[t]{2}{*}{0.738} \\
\hline$>53 \mathrm{~Gy}_{10}$ & 7 & 5 & \\
\hline \multicolumn{4}{|l|}{ Combination therapy } \\
\hline $\begin{array}{l}\text { Radiation therapy } \\
\text { alone }\end{array}$ & 9 & 10 & \multirow[t]{2}{*}{0.444} \\
\hline $\mathrm{CCRT}^{\dagger}$ & 17 & 12 & \\
\hline \multicolumn{4}{|l|}{ TNM stage } \\
\hline III & 16 & 9 & \multirow[t]{2}{*}{0.185} \\
\hline IV & 10 & 13 & \\
\hline \multicolumn{4}{|l|}{$\mathrm{AFP}^{\ddagger}$} \\
\hline$\leq 400$ & 9 & 11 & \multirow{2}{*}{0.281} \\
\hline$>400$ & 17 & 11 & \\
\hline \multicolumn{4}{|l|}{ Child-Pugh class } \\
\hline A & 20 & 18 & \multirow[t]{2}{*}{0.677} \\
\hline B & 6 & 4 & \\
\hline \multicolumn{4}{|c|}{ Portal vein thrombosis } \\
\hline Main trunk & 9 & 6 & \multirow[t]{3}{*}{0.587} \\
\hline First branch & 13 & 10 & \\
\hline Second branch & 4 & 6 & \\
\hline \multicolumn{4}{|l|}{ Previous treatment } \\
\hline $\mathrm{TACE}^{\S}$ or PEIT & 19 & 18 & \multirow[t]{2}{*}{0.515} \\
\hline No treatment & 7 & 4 & \\
\hline
\end{tabular}

*Eastern Cooperative Oncology Groupy, ${ }^{\dagger}$ concurrent chemoradiation therapy, ${ }^{\ddagger}$ alpha-fetoprotein, ${ }^{\circ}$ transarterial chemoembolizaion, "percutaneous ethanol injection therapy, "using Fisher's exact test.

exists. $^{23,24)}$ The American Association for the Study of Liver Diseases guideline recommends sorafenib when there is portal invasion for palliative aim. However, the recommendation is limited because of limited safety data in Child-Pugh class B patients and uncertainty of using dosage. ${ }^{25)}$

RT in HCC with PVTT tends to improve survival about 8 $\sim 13$ months. $^{10 \sim 14)} \mathrm{Kim}$ et al. ${ }^{14)}$ analyzed 70 patients with PVTT treated using RT doses of 40 to 60 Gy (median, 48 Gy), RT was effective (response rate, 47.1\%; median survival, 11 months) and safe. These authors also reported that RT responders showed better survival (median survival 15 vs. 8 months, $\mathrm{p}=0.034$ ). Consistently, the present study also identified a survival benefit associated with RT (median survival, 9 months). Tumor response was observed in 26 patients $(54.2 \%)$, and there was also a survival difference between responders and non-responders. However, we were unable to identify the factors affecting RT response.

Zeng et al. $^{13)}$ compared combination therapies with or without external beam radiation therapy (EBRT). In their comparison, the EBRT group was treated with TACE $(n=25)$, surgery $(n=9)$ or RT alone $(n=10)$. The non-EBRT group was treated with TACE $(n=73)$, surgery $(n=18)$ or RT alone $(n=23)$. The combination therapy involving RT was associated with a survival benefit (median survival 8 vs. 4 months, $p$ $<0.0001$ ). In our study, 39 of 50 patients received TACE or PEIT before RT, but there were no statistical differences in survival time and tumor response.

Systemic chemotherapy has been regarded as ineffective because of its lack of responsiveness or high rate of toxicity. However, HAIC confers a therapeutic benefit because of its increased local concentration and lower systemic toxicity, even in advanced HCC with PVTT. ${ }^{23,26)}$ CCRT has been investigated to maximize the therapeutic effect and minimize the treatment-related complications. Han et al. ${ }^{10)}$ conducted a clinical trial of CCRT for HCC with PVTT, and demonstrated substantial tumor response rate (objective response, 45\%) and survival benefit (median survival time, 13.1 months). Katamura et al. $^{27)}$ reported that combination therapy with HAIC and three-dimensional conformal radiotherapy improved response rate $(75 \%$ vs. $25 \%, \mathrm{p}=0.012)$ and reduced the incidence of portal hypertension related events such as variceal bleeding or uncontrolled ascites. These authors also reported a higher response rate when using combination therapy, compared with conformal therapy alone. ${ }^{27,28)}$ However, in our study, the median survival time and survival rate was better in patients receiving RT but not chemotherapy $(\mathrm{p}=0.034)$. The result may be due to patient differences, although statistical analyses did not reveal differences between the groups. However, the CCRT group did display poor characteristics such as PVTT invasiveness (4 patients with main trunk invasion in the RT alone group vs. 12 patients with main trunk invasion in the CCRT group) or Child-Pugh classification (3 patients in class $\mathrm{B}$ in RT alone group vs. 8 patients in class B in CCRT group). On the other hand, the result may indicate that HAIC can induce complications including hepatobiliary toxicity or hepatic artery occlusion. ${ }^{29)}$ Especially, hepatic artery occlusion 
may induce hypoxia, which can affect the efficacy of radiation.

Zeng et al. ${ }^{15)}$ studied prognostic factors for patients with HCC with PVTT who received RT. In the study, the prognostic factors were categorized into three groups: tumor-related factors $(\gamma$-glutamyltransferase, AFP, tumor size, intrahepatic metastases, lymph nodal status and distant metastases), liver function-related factors (total bilirubin, albumin, liver enzyme and Child-Pugh classification) and treatment-related factors (previous treatment modalities, radiation technique and response to radiotherapy). The authors reported that lower albumin, higher $\gamma$-glutamyltransferase, AFP level, poor Child-Pugh classification, multiple hepatic metastases and lymph nodal metastases were pretreatment unfavorable predictors. Our study included several similar factors, including tumor-related and liver function-related factors. CLIP stage, which reflects both tumor extent and liver function including Child-Pugh classification can be prognostic, ${ }^{18,20)}$ as can the TNM staging system, which includes tumor size, vessel invasiveness and tumor numbers. ${ }^{19,30)}$ The present study was retrospective in design and involved a small sample size. Hence, most differences were not statistically significant. Yet, staging systems including laboratory values were statistically significant.

Several guidelines are suggested to save the normal liver and minimize liver toxicity. ${ }^{21,22,31,32)}$ In guideline published by the University of Michigan, $\mathrm{V}_{50 \%}$ is divided into three intervals $(<33 \%, 33 \sim 66 \%,>66 \%)$ and the guideline recommends a total dose irradiation of $66 \sim 72 \mathrm{~Gy}, 48 \sim 52.8 \mathrm{~Gy}$ and $36 \mathrm{~Gy}$, respectively. ${ }^{22)}$ In guideline published by the Yonsei University, $\mathrm{V}_{50 \%}$ is divided into four intervals $(<25 \%$, $25 \sim 49 \%, 50 \sim 75 \%,>75 \%$ ) and the recommended total dose is $>59.4 \mathrm{~Gy}, 45 \sim 54 \mathrm{~Gy}, 30.6 \sim 45 \mathrm{~Gy}$ and no treatment for $\mathrm{V}_{50 \%}>75 \%$. $^{21)}$ In our study, $\mathrm{V}_{50 \%}$ ranged from 14.9 to $64.0 \%$ (median, 37.0\%). Total dose irradiated ranged from 30 to 54 Gy (median, 45 Gy). The $\mathrm{V}_{50 \%}$ and total dose irradiated were compatible to both of the aforementioned guidelines. Also the patients in this study had relatively good hepatic function considering Child-Pugh classification or CLIP staging system, and RT was delivered in conventional fractionation size $(1.8 \sim$ 2.0 Gy once a day). Therefore, the result of no RILD seems reasonable. However, this cannot be a definite conclusion, because RILD was evaluated through retrospective methods and because RILD criteria are less firm for patients with icteric condition or elevated bilirubin counts, which represents combined modality-induced liver disease. ${ }^{33)}$ As well, a total treatment dose $>30$ Gy was selected, so acute toxicity was excluded in our study.

In cases of HCC with PVTT, RT is an effective and safe modality. There were compatible results with other studies. Further studies including prospective randomized trials are needed to confirm the role of RT for HCC with PVTT.

\section{References}

1. Bosch FX, Ribes J, Diaz M, Cleries R. Primary liver cancer: worldwide incidence and trends. Gastroenterology 2004;127(5 Suppl 1):S5-S16

2. Parkin DM, Bray F, Ferlay J, Pisani P. Global cancer statistics, 2002. CA Cancer J Clin 2005;55:74-108

3. Minagawa M, Makuuchi $M$. Treatment of hepatocellular carcinoma accompanied by portal vein tumor thrombus. World J Gastroenterol 2006;12:7561-7567

4. Takizawa D, Kakizaki S, Sohara N, et al. Hepatocellular carcinoma with portal vein tumor thrombosis: clinical characteristics, prognosis, and patient survival analysis. Dig Dis Sci 2007;52:3290-3295

5. Yeung YP, Lo CM, Liu CL, Wong BC, Fan ST, Wong J. Natural history of untreated nonsurgical hepatocellular carcinoma. Am J Gastroenterol 2005;100:1995-2004

6. Kumada K, Ozawa K, Okamoto R, et al. Hepatic resection for advanced hepatocellular carcinoma with removal of portal vein tumor thrombi. Surgery 1990;108:821-827

7. Tanaka A, Morimoto T, Yamaoka Y. Implications of surgical treatment for advanced hepatocellular carcinoma with tumor thrombi in the portal vein. Hepatogastroenterology 1996; 43:637-643

8. Yamada R, Sato $M$, Kawabata $M$, Nakatsuka $H$, Nakamura K, Takashima S. Hepatic artery embolization in 120 patients with unresectable hepatoma. Radiology 1983;148: 397-401

9. Okada S. Transcatheter arterial embolization for advanced hepatocellular carcinoma: the controversy continues. Hepatology 1998;27:1743-1744

10. Han KH, Seong J, Kim JK, Ahn SH, Lee do Y, Chon CY. Pilot clinical trial of localized concurrent chemoradiation therapy for locally advanced hepatocellular carcinoma with portal vein thrombosis. Cancer 2008;113:995-1003

11. Huang $\mathrm{YJ}, \mathrm{Hsu} \mathrm{HC}$, Wang $\mathrm{CY}$, et al. The treatment responses in cases of radiation therapy to portal vein thrombosis in advanced hepatocellular carcinoma. Int $\mathrm{J}$ Radiat Oncol Biol Phys 2009;73:1155-1163

12. Nakagawa K, Yamashita $\mathrm{H}$, Shiraishi $\mathrm{K}$, et al. Radiation therapy for portal venous invasion by hepatocellular carcinoma. 
World J Gastroenterol 2005;11:7237-7241

13. Zeng ZC, Fan J, Tang ZY, et al. A comparison of treatment combinations with and without radiotherapy for hepatocellular carcinoma with portal vein and/or inferior vena cava tumor thrombus. Int J Radiat Oncol Biol Phys 2005;61:432-443

14. Kim JH, Choi EK, Ahn SD, et al. The role of radiotherapy in the treatment of portal vein thrombosis from advanced hepatocellular carcinoma. J Korean Soc Ther Radiol Oncol 2007;25:170-176

15. Zeng ZC, Fan J, Tang ZY, et al. Prognostic factors for patients with hepatocellular carcinoma with macroscopic portal vein or inferior vena cava tumor thrombi receiving external-beam radiation therapy. Cancer Sci 2008;99:2510-2517

16. Korean Liver Cancer Study Group and National Cancer Center, Korea. Practice guidelines for management of hepatocellular carcinoma 2009. Korean J Hepatol 2009;15:391-423

17. Zirinsky K, Markisz JA, Rubenstein WA, et al. MR imaging of portal venous thrombosis: correlation with $\mathrm{CT}$ and sonography. AJR Am J Roentgenol 1988;150:283-288

18. Prospective validation of the CLIP score: a new prognostic system for patients with cirrhosis and hepatocellular carcinoma. The Cancer of the Liver Italian Program (CLIP) Investigators. Hepatology 2000;31:840-845

19. Ikai I, Takayasu K, Omata M, et al. A modified Japan Integrated Stage score for prognostic assessment in patients with hepatocellular carcinoma. J Gastroenterol 2006;41:884-892

20. Seong J, Shim SJ, Lee IJ, Han KH, Chon CY, Ahn $\mathrm{SH}$. Evaluation of the prognostic value of Okuda, Cancer of the Liver Italian Program, and Japan Integrated Staging systems for hepatocellular carcinoma patients undergoing radiotherapy. Int J Radiat Oncol Biol Phys 2007;67:1037-1042

21. Lee IJ, Seong J, Shim SJ, Han KH. Radiotherapeutic parameters predictive of liver complications induced by liver tumor radiotherapy. Int J Radiat Oncol Biol Phys 2009;73: 154-158

22. Robertson JM, Lawrence TS, Dworzanin LM, et al. Treatment of primary hepatobiliary cancers with conformal radiation therapy and regional chemotherapy. J Clin Oncol 1993;11:1286-1293

23. Llovet JM. Updated treatment approach to hepatocellular carcinoma. J Gastroenterol 2005;40:225-235

24. Bruix J, Sherman M. Practice Guidelines Committee, American Association for the Study of Liver Diseases. Management of hepatocellular carcinoma. Hepatology 2005;42:1208-1236

25. Miller AA, Murry DJ, Owzar K, et al. Phase I and pharmacokinetic study of sorafenib in patients with hepatic or renal dysfunction: CALGB 60301. J Clin Oncol 2009;27:1800-1805

26. Leung TW, Johnson PJ. Systemic therapy for hepatocellular carcinoma. Semin Oncol 2001;28:514-520

27. Katamura $\mathrm{Y}$, Aikata H, Takaki S, et al. Intra-arterial 5-fluorouracil/interferon combination therapy for advanced hepatocellular carcinoma with or without three-dimensional conformal radiotherapy for portal vein tumor thrombosis. J Gastroenterol 2009;44:492-502

28. Toya R, Murakami R, Baba $Y$, et al. Conformal radiation therapy for portal vein tumor thrombosis of hepatocellular carcinoma. Radiother Oncol 2007;84:266-271

29. Barnett KT, Malafa MP. Complications of hepatic artery infusion: a review of 4580 reported cases. Int J Gastrointest Cancer 2001;30:147-160

30. Ikai I, Arii S, Kojiro M, et al. Reevaluation of prognostic factors for survival after liver resection in patients with hepatocellular carcinoma in a Japanese nationwide survey. Cancer 2004;101:796-802

31. Mornex F, Girard N, Beziat C, et al. Feasibility and efficacy of high-dose three-dimensional-conformal radiotherapy in cirrhotic patients with small-size hepatocellular carcinoma non-eligible for curative therapies--mature results of the French Phase II RTF-1 trial. Int J Radiat Oncol Biol Phys 2006:66:1152-1158

32. Xu ZY, Liang SX, Zhu J, et al. Prediction of radiation-induced liver disease by Lyman normal-tissue complication probability model in three-dimensional conformal radiation therapy for primary liver carcinoma. Int J Radiat Oncol Biol Phys 2006;65:189-195

33. Shim SJ, Seong J, Lee IJ, Han KH, Chon CY, Ahn $\mathrm{SH}$. Radiation-induced hepatic toxicity after radiotherapy combined with chemotherapy for hepatocellular carcinoma. Hepatol Res 2007;37:906-913 


\title{
간문맥종양혈전증을 동반한 간세포암에서의 방사선 치료
}

\author{
계명대학교 의과대학 동산의료원 방사선종양학교실*, 소화기내과학교실 ${ }^{\dagger}$, 의공학교실 $^{\ddagger}$ \\ 박승규* · 김진희* · 변상준* · 김옥배* · 황재석 ${ }^{\dagger} \cdot$ 오영기* · 최태진 ${ }^{\dagger}$
}

목 적: 간문맥종양혈전증을 동반한 간세포암에서 방사선 치료의 효과와 이에 영향을 미치는 인자들에 대해 알아보 기 위하여 연구를 계획하였다.

대상 및 방법: 2004년 12월부터 2009년 4월까지 계명대학교 동산의료원 방사선종양학과에서 간세포종양에 의한 간문맥 혈전부위에 방사선 치료를 받은 환자는 70 명이었고 그 중 $30 \mathrm{~Gy}$ 미만의 방사선 조사를 받은 19 명의 환자와 간이식을 시행한 1 명의 환자를 제외한 50 명의 환자를 대상으로 하였다. 성별 구성은 남성이 45 명, 여성이 5 명이었 고, 연령분포는 32세에서 79세(중앙값, 55세)이었다. 39명의 환자가 방사선 치료 전 간동맥 화학 색전술, 경피적 에탄올 주입술 등의 시술을 받았다. TNM 병기에 따른 분류는 III기 27명(54.0\%), IV기 23명(46.0\%)이었다. 방사선 치료는 총 조사선량 30 54 Gy (중앙값, 45)의 외부방사선을 조사하였으며, 이 중 동시항암화학방사선 치료를 받 은 환자는 30 명 $(60.0 \%)$ 이었다. 추적관찰기간은 3 개월에서 70 개월(중앙값, 13.5$)$ 이었다.

결 과: 방사선치료 시작부터 전체 환자의 중앙생존기간은 9 개월이었고, 1 년 생존률은 $24.9 \%$, 2년 생존률은 $11.2 \%$ 이었다. 현재 무병생존은 3명(6.0\%), 유병생존은 7명(14.0\%), 질병악화로 인한 사망은 40 명(80.0\%)이었다. 생존율 에 영향을 미치는 인자에 대한 단변량분석 상, 동시항암화학방사선 치료는 방사선치료 단독치료보다 낮은 생존율 을 보였다 $(\mathrm{p}=0.034)$. 방사선치료에 대한 종양의 반응 $(\mathrm{p}=0.037), \mathrm{CLIP}$ 병기 $(\mathrm{p}=0.017), \mathrm{TNM}$ 병기 $(\mathrm{p}=0.041)$ 가 통계적 으로 유의한 결과를 보였다. 방사선에 의한 간독성은 관찰되지 않았다.

결 론: 간문맥종양혈전을 동반한 간세포암에서 방사선치료는 안전하게 생존율의 향상을 얻을 수 있는 방법으로 생 각된다. 향후 간문맥종양혈전을 동반한 간세포암에서 방사선치료의 역할을 알아보기 위한 무작위 전향적 임상연구 가 필요하리라 생각된다.

핵심용어: 간세포암, 간문맥, 방사선치료, 동시항암화학방사선치료 